\title{
Local People's Perception on Climate Change, its Indicators and Adaptation Strategies in the Chitwan-Annapurna Landscape, Nepal
}

\author{
Jagan Nath Adhikari, ${ }^{1,2}$ Bishnu Prasad Bhattarai ${ }^{1 *}$ and Tej \\ BahadurThapa ${ }^{1}$ \\ ${ }^{1}$ Central Department of Zoology, Tribhuvan University, Nepal \\ ${ }^{2}$ Birendra Multiple Campus, Tribhuvan University, Nepal \\ Research Article \\ Volume 3 Issue 1 \\ Received Date: December 13, 2018 \\ Published Date: January 07, 2019 \\ DOI: $10.23880 /$ jenr-16000153
}

*Corresponding author: Bhishnu P Bhattarai, Central Department of Zoology, Institute of Science and Technology, Tribhuvan University, Kathmandu, Nepal, Tel: (977-1) 4331896; Email: bpbhattarai@cdztu.edu.np

\begin{abstract}
Climate change is regarded as one of the main obstacles to the environment conservation and people's economy, agriculture and livelihood in undeveloped countries like Nepal. Understanding people's perception and indicators of climate change are fundamental knowledge for developing various adaptation strategies. This study was based on the questionnaire survey with respondents of 204 households in the study area- Chitwan Annapurna Landscape, Nepal. More than $92 \%$ of the respondents were perceived the problems of climate change such as low or unprecedented rainfall, the rate of dryness of the land, dryness of wetlands, change crop pattern and phenology. These indicators of climate change were significantly increased in the recent years. Local people have been facing various levels of impacts caused by invasive alien plant species in their farmlands and forests $(87.7 \%)$ and that also replaced the pasture or grasslands (69.1\%). Besides, local people have experienced the increased rate of tropical disease vectors (e.g., house flies and mosquitoes), pests on crops and livestock diseases over the last 15 years. The rain water harvesting technology adopted by local people is the major adaptation strategy during low rainfall and dry periods. Likewise, the local people use invasive alien plant species to make bio-briquettes, fodders, cattle beds and compost manures. However, the lack of sufficient knowledge and resources, people's livelihood is vulnerable under such worst situation due to climate change. Therefore, it is necessary to focus on capacity building of local people to adapt with changing climate.
\end{abstract}

Keywords: Climate Change; Adaptation Strategy; People’s Perceptions; Midhill; Nepal

\section{Introduction}

The recent researches have shown human facing the challenges for their socio-economic activities, health, livelihood, and food security due to climate change [1-5]. The climate change has been seriously affected developed and undeveloped countries, poor and rich people [6]. Undeveloped countries are more vulnerable than 
developed countries as the developed countries can develop various adaptive measures to cope with the climate change [7]. Rural people are likely to be more vulnerable to climate change, particularly because of compounding challenges of poverty, low infrastructural and technological development and high dependence on rain-fed agriculture $[1,8,9]$. More than $80 \%$ of agricultural production in Hilly region of Nepal is rain-fed [10]. The mountain and midhill regions of Nepal is greatly affected by the climate change than in Terai [3]. The solution to cope with climate change for the marginal people of Nepal seems to develop adaptation strategies. The recent studies have been indicated that there is a large deficit of knowledge and information about the climate change and related adaptation strategies to mitigate risk of climate change $[8,10]$. Present study highlights responses of people towards the indicators of climate change and status of public awareness in human dominated midhill landscape- Chitwan Annapurna Landscape.

\section{Materials and Methods}

\section{Study Area}

The study area encompasses landscape that connects the Chitwan National Park in lowland Terai with the Annapurna Conservation Area in the high mountain region. This region lies in the centre of the central
Himalayas and represents globally outstanding biodiversity. It includes three WWF 200 global ecoregions (Terai-duar savanna and grasslands, Himalayan subtropical broadleaf forests, alpine shrubs and meadows), and two Ramsar sites (Beeshazari lake, Chitwan and lake clusters in Pokhara valley) [11] http://nepallake.gov.np/. The area is key habitats for many species such as tiger, rhinoceros, common/clouded/snow leopards, sloth/Himalayan black bears, sambar deer, spotted deer, musk deer, Himalayan goral, Himalayan tahr etc. The major forest patches that make the potential vertical corridor in this area are Barandabhar corridor forest, Gaighat area, Seti and Kali Gandaki river basin and Panchase protected forest area. The intensive study area covers Tanahun, Kaski and a part of Syanja and Parbat districts with an area of $2742.84 \mathrm{~km}^{2}$ (Figure 1). The whole study area is divided into three different study blocks depending upon altitude, geography, location and accessibility. They are: Block A: Panchase area Block B: Rishing and Ghiring area, Block C: Devghat and Gaighat area. This area is highly human dominated and fragmented ranges from $175 \mathrm{~m}$ to $2250 \mathrm{~m}$ altitude. Most of people depend upon the agriculture and animal husbandry. The ethnic community of the study area feel different types of climatic and biological changes to their localities due to climate change.

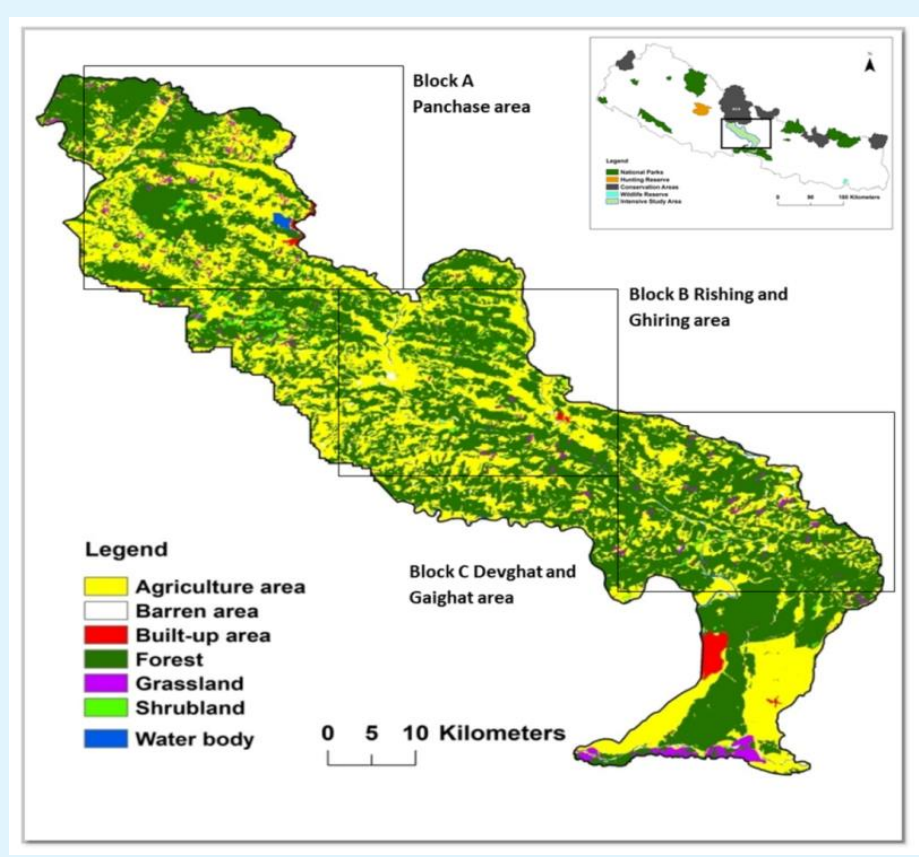

Figure 1: Map showing the intensive study area which links two biodiversity significant areas- CNP and ACA (Source: ICIMOD/DNPWC 2018). 


\section{Methods}

\section{Sampling Size and Techniques}

This study was based on the questionnaire survey among the local people in three study blocks. The participants (respondents) for this survey were randomly selected [12,13]. A total of 204 respondents (86 from Block A, 69 from Block B and 49 from Block C) were sampled by using the structured questionnaires related to the indicators and perceptions on climate change. From the sampling frame, the sample units were selected above the age of 30 years, so that they can able to recall signs of patterns of climate changes in their communities. Structural questionnaire was the major tools of data collection. The questionnaire was translated into the Nepali language by interviewers. In Nepal, males are the head of the family and therefore most of the respondents involved in this sampling were males than females (Male=134, Female=70, $S D=45.25$ ). But during the interview, no hints on climate change were provided to the respondents to avoid possible biasness as indicated by Mertz 0, et al. [14]. If the discussion was made on their perceptions of climate change, they had made some changes on their original view of climate change and adaptive measures when in fact they had not $[15,16]$.

\section{Data Analysis}

Data obtained from the questionnaires and interviews were categorized on the basis of people's perceptions on climate change and their mitigation methods into tabular forms. The data were analysed by using the PAST software. Multi variant ANOVA was used to measure the significant level of the perceptions of change in climate.

\section{Results and Discussion}

\section{Descriptive Information of the Respondents}

The personal, social and economic characteristics of the respondents of the study area (such as age, occupations, gender, education status, caste system, economic status) are presented in Table 1 . The results of the questionnaires found that the respondents in the study area were 32 to 83 years (Mean=51.04, SD=10.91). Most of the respondents were literate $(37.75 \%)$ have more experience on agriculture, animal husbandry and local society. The average annual income of the respondents was 25862.75 NRs (USD 253.75) which is very low than national per capita income (USD 682.22) [17]. Similar pattern of income of the respondents were found in the Nepalese Ruler communities $[17,18]$. The major income sources of respondents were agriculture, business, government job, wedges and remittances. Remittance covered $32.13 \%$ of the total income (Table 1). Most popular ethnic groups that inhabitant in Midhill Nepal are Gurung, Magar, Tamnag, Dalit, Braman, Chhetri, Ghale etc [19]. Most of the respondents were Gurung (27.94\%) followed by Dalit (22.55\%) and Magar (21.57\%).

\begin{tabular}{|c|c|c|c|c|c|c|c|c|}
\hline \multirow{2}{*}{$\begin{array}{l}\text { Respondents } \\
\text { features }\end{array}$} & \multirow{2}{*}{ Categories } & \multirow{2}{*}{ Scoring method } & \multirow{2}{*}{$\begin{array}{c}\text { No of } \\
\text { respondents }\end{array}$} & \multirow{2}{*}{$\%$} & \multicolumn{2}{|c|}{ Range } & \multirow{2}{*}{ Mean } & \multirow{2}{*}{$\begin{array}{l}\text { Standard } \\
\text { Deviation }\end{array}$} \\
\hline & & & & & Max & Min & & \\
\hline \multirow{6}{*}{ Age } & $30-39$ & \multirow{6}{*}{ Years } & 29 & 14.22 & \multirow{6}{*}{83} & \multirow{6}{*}{32} & \multirow{6}{*}{51.04} & \multirow{6}{*}{10.91} \\
\hline & $40-49$ & & 64 & 31.37 & & & & \\
\hline & 50-59 & & 78 & 38.23 & & & & \\
\hline & $60-69$ & & 19 & 9.31 & & & & \\
\hline & $70-79$ & & 12 & 5.88 & & & & \\
\hline & Above 80 & & 2 & 0.98 & & & & \\
\hline \multirow{7}{*}{ Occupation } & Farmer & \multirow{7}{*}{ Number } & 83 & 40.69 & & & & \multirow{7}{*}{25.002} \\
\hline & Students & & 17 & 8.33 & & & & \\
\hline & Teacher & & 25 & 12.25 & & & & \\
\hline & Social workers & & 22 & 10.78 & & & & \\
\hline & Govern. Employer & & 16 & 7.84 & & & & \\
\hline & Hotel owner & & 8 & 3.92 & & & & \\
\hline & Business & & 33 & 16.18 & & & & \\
\hline \multirow{2}{*}{ Gender } & Female & \multirow{2}{*}{ Number } & 70 & 34.31 & & & & \multirow{2}{*}{45.25} \\
\hline & Male & & 134 & 65.69 & & & & \\
\hline \multirow{2}{*}{ Education status } & Iliterate & \multirow{2}{*}{ Year of schooling } & 24 & 11.76 & & & & \multirow{2}{*}{23.99} \\
\hline & Literate & & 77 & 37.75 & & & & \\
\hline
\end{tabular}




\section{Journal of Ecology \& Natural Resources}

\begin{tabular}{|c|c|c|c|c|c|}
\hline & Secondary & & 54 & 26.47 & \\
\hline & Intermediate & & 26 & 12.75 & \\
\hline & University & & 23 & 11.27 & \\
\hline \multirow{9}{*}{ Caste system } & Dalit & \multirow{9}{*}{ Number } & 46 & 22.55 & \multirow{9}{*}{20.45} \\
\hline & Gurung & & 57 & 27.94 & \\
\hline & Magar & & 44 & 21.57 & \\
\hline & Newar & & 11 & 5.39 & \\
\hline & Tamang & & 14 & 6.86 & \\
\hline & Darai & & 2 & 0.98 & \\
\hline & Sanyasi & & 15 & 7.35 & \\
\hline & Braman & & 12 & 5.88 & \\
\hline & Gharti & & 3 & 1.47 & \\
\hline \multirow{5}{*}{ Income } & Service & \multirow{5}{*}{ NRs } & 644000 & 12.21 & \multirow{5}{*}{618496.7} \\
\hline & Business & & 1335000 & 25.30 & \\
\hline & Agriculture & & 1411000 & 26.74 & \\
\hline & Remit & & 1695000 & 32.13 & \\
\hline & Wedges & & 191000 & 3.62 & \\
\hline
\end{tabular}

Table 1: Descriptive information of the respondents.

\section{People's Perceptions on Climate Change}

The respondents of the study area were asked dichotomous questions (Yes/No question) about whether they felt or perceived the experiences of climate change or not? More than $92 \%$ of the respondents were perceived the experience of climate change in their area (Figure 2). These types of the studies conducted in Bangaldesh [20], India [21,22] and Nepal [3,23-25] also found the similar results.

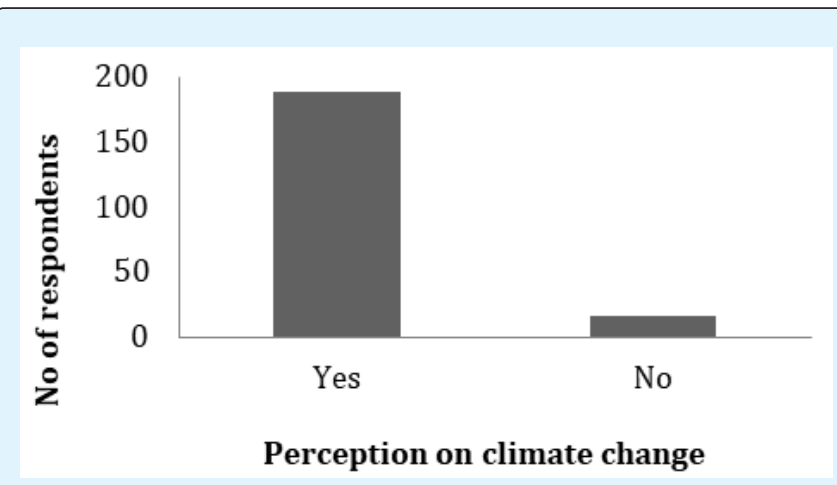

Figure 2: Do you feel the climate change?

The local peoples of the study area perceived direct feeling of climate change present days and past years. The questions were designed if they are feeling the condition of climate change these days and past years by giving four options- bad, very bad, constant and good. More than $80 \%$ of the respondents said the good condition of the climate before past 15 years, but now they felt bad (51.4\%) and very bad (37.25\%) climate. The relationship between the feeling of such climatic condition in the past and the present showed very bad situation of climate in these days. Similar researches in different parts of Nepal also indicated the similar type of the feelings $[10,23,26,27]$.

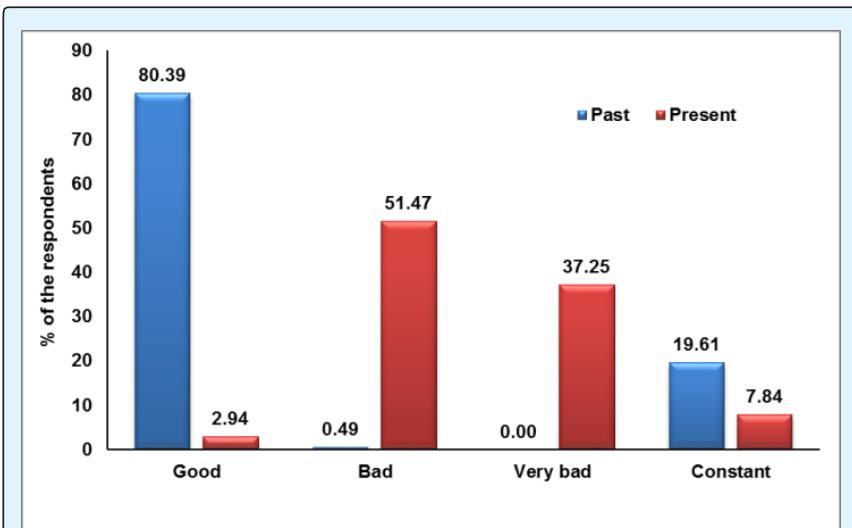

Figure 3: Relation between feelings of the respondents on climate- past (15 years ago) and present.

\section{Locals' Perception on Experiences on Climate Change}

Some climatic variables such as temperature, unpredictable rainfall, wind or storm rate, solar radiation, dryness of the land and dryness of the rivers and streams or wetlands were fixed and asked to the respondents by 
providing the options of increased, decreased, constant and don't know. Majority of the locals felt increasing the temperature (98\%) and solar radiation (79.9\%). Rainfall is also another major indicator of climate change. But in this category, local people were not able to express the exact feeling due to unpredictable rainfall; however, more respondents were agreed on decreasing unpredictable rainfall $(46.1 \%)$. There is no clear view about the rate of storms and winds. Most of the local people felt on decreasing the wind velocity due to increase of forest area, they believed that tall trees blocked the speed of the wind. Due to low rainfall, the rate of dryness of the land and dryness of streams, rivers and other wetlands were significantly increased in the recent years $(F=4.95, d f=23$, $p=0.009$ ) (Table 2). As found in our study area, the perceptions of the respondents coincide with the trends observed in many parts of the world suggesting that temperature is rising and precipitation is falling Tambo \& Abdoulaye [29], Roco, et al. [30]. Similar findings have been reported in the studies conducted in Ethiopia [28], Bangladesh [20], Nigeria [29], Chile [30], India [6,31], Bhutan [32] and other parts of Nepal [26].

\begin{tabular}{|c|c|c|c|c|}
\hline \multirow{2}{*}{ Climatic events } & \multicolumn{4}{|c|}{ \% of respondents } \\
\cline { 2 - 5 } & Increased & Decreased & Constant & Don't know \\
\hline Temperature & 98.0 & 0.0 & 0.0 & 2.0 \\
\hline Unpredictable rainfall & 1.0 & 46.1 & 24.5 & 29.4 \\
\hline Rate winds/storms & 19.6 & 49.0 & 0.0 & 31.4 \\
\hline Solar radiation & 79.9 & 1.0 & 12.3 & 6.9 \\
\hline Rate of dryness of lands & 72.1 & 0.0 & 11.3 & 17.2 \\
\hline Dry rate of rivers and streams & 72.1 & 0.5 & 12.3 & 15.7 \\
\hline
\end{tabular}

Table 2: Distribution of the responses perceived by the respondents about climatic events $(n=204)$.

\section{People's Perception on Biological Changes}

Most of the respondents of the study area felt on the biological changes directly and indirectly due to climate change. Eight variables of biological changes had been identified and asked to the respondents by providing the four options increased, decreased, constant and don't know. The responses of the respondents on biological changes of the surrounding showed the significant results on analysing in multivariate ANOVA $(F=17.08, d f=31$, $p=0.0001$ ). Most of the respondents felt on increasing prevalence on crops (73\%), livestock (82.4\%) and human
(83.8\%). They also had the bitter feeling about the invasion of invasive alien plant species in their farms and forests $(87.7 \%)$ and decreased on the pasture or grasslands (69.1\%). According to the respondents, the occurrence rate of mosquitoes and house fly was increased (85.3\%) in these days. Most of the respondent of midhills had the bitter experiences on changing the plant phenology (55.9\%) (Table 3). Many research conducted in different parts of the world suggested similar type of increases in infection rate of the diseases on crops, livestock and man [33-36].

\begin{tabular}{|c|c|c|c|c|c|c|c|c|}
\hline \multirow{2}{*}{ Biological changes } & \multicolumn{2}{|c|}{ Increased } & \multicolumn{2}{|c|}{ Decreased } & \multicolumn{2}{c|}{ Constant } & \multicolumn{2}{c|}{ Don't know } \\
\cline { 2 - 9 } & $\mathbf{F}$ & $\mathbf{\%}$ & $\mathbf{F}$ & $\mathbf{\%}$ & $\mathbf{F}$ & $\mathbf{\%}$ & $\mathbf{F}$ & \% \\
\hline Infection of disease on crops & 149 & 73.0 & 0 & 0.0 & 21 & 10.3 & 35 & 17.2 \\
\hline Infection of disease on livestock & 168 & 82.4 & 0 & 0.0 & 10 & 4.9 & 25 & 12.3 \\
\hline Infection of disease on human & 171 & 83.8 & 0 & 0.0 & 15 & 7.4 & 18 & 8.8 \\
\hline Pasture/grassland & 0 & 0.0 & 141 & 69.1 & 37 & 18.1 & 26 & 12.7 \\
\hline Tropical disease vectors & 174 & 85.3 & 0 & 0.0 & 16 & 7.8 & 14 & 6.9 \\
\hline Invasive and alien plant species & 179 & 87.7 & 0 & 0.0 & 12 & 5.9 & 11 & 5.4 \\
\hline Crop pests & 148 & 72.5 & 0 & 0.0 & 29 & 14.2 & 27 & 13.2 \\
\hline Change in plant phenology & 114 & 55.9 & 1 & 0.5 & 36 & 17.6 & 53 & 26.0 \\
\hline
\end{tabular}

Table 3: Responses of respondents on biological change of the surrounding due to climate change. (Where $\mathrm{F}$ is the frequency or number of the respondents). 


\section{Journal of Ecology \& Natural Resources}

\section{Adaptation Strategy}

Undeveloped countries like Nepal are more vulnerable than the developed countries as the developed countries can develop problem focussed adaptive measures to cope with the climate change. Local people in Nepal use different indigenous and traditional strategies to manage risks related to climate. However, this is essential for famers and herders not only to cope with the impacts of the climate change but also to adapt to reduce negative impact of climate change. Socioeconomic and environmental factors have played the vital role to adapt with the impacts of a changing climate [33,37]. The respondents were asked about the 12 different variables related with climatic and biological changes providing multiple options of adaptation strategies. Most of the respondents felt the low crop production due to increased temperature, decreased rainfall and dryness of lands and think in changing the crops (Table 4). They also initiated the rain water harvesting technology for irrigation and drinking during decreased water level in the rivers and streams. For controlling the alien and invasive plant species in the farms and forests, the local people initiated the controlling mechanisms such as removal of these plants and used to make bio-briquettes, compose manures and also used as fodders. Some community leaders felt on the change in plant phenology and said fast blooming of the fruiting plants than their regular time and now they are thinking to change the fruiting plants and crops $(n=109)$. The respondents made a plan to use insects and disease resistant varieties of the crops to cope with infections of diseases and insects on crops. The respondents thought that there were no options of treatments of diseases on livestock and man. Adaptive capacity of small farmers to cope with changes in climatic events is usually low due to dependence on natural resources, poor infrastructure and low income rate $[3,10,38]$. Similar type of the problem was also observed in our study area. In some parts of the study area, the people have strong faith in spiritual interventions and perform rain calling rituals and marriage of the frogs to make their gods happy so that the god rewards the rain and good harvests (Personal communication with Jash Bahadur Gurung, Chairman of Kyadigaura Community forest, Ghiring-3, Archalbot, Tanahun). Similar types of adaptation strategy to cope with climate change were reported by the researchers from the different parts of the country $[4,10,26]$.

\begin{tabular}{|c|c|c|c|c|c|c|c|}
\hline Variables & $\mathbf{F}$ & $\begin{array}{c}\text { Adaptation } \\
\text { measures }\end{array}$ & $\mathbf{F}$ & $\begin{array}{c}\text { Adaptation } \\
\text { measures }\end{array}$ & $\mathbf{F}$ & $\begin{array}{c}\text { Adaptation } \\
\text { measures }\end{array}$ & $\mathbf{F}$ \\
\hline Temperature increased & $\begin{array}{c}17 \\
9\end{array}$ & $\begin{array}{l}\text { Changing on the } \\
\text { crops }\end{array}$ & $\begin{array}{c}14 \\
5\end{array}$ & Plantation & $\begin{array}{l}1 \\
2 \\
2\end{array}$ & & \\
\hline Unpredictable rainfall & $\begin{array}{c}20 \\
4\end{array}$ & $\begin{array}{l}\text { Changing on the } \\
\text { crops }\end{array}$ & $\begin{array}{c}18 \\
0\end{array}$ & Planting fruit plants & $\begin{array}{l}4 \\
5\end{array}$ & & \\
\hline Increased dryness of lands & $\begin{array}{c}14 \\
7\end{array}$ & $\begin{array}{l}\text { Changing on the } \\
\text { crops }\end{array}$ & $\begin{array}{c}13 \\
5\end{array}$ & Planting fruit plants & $\begin{array}{l}5 \\
5\end{array}$ & & \\
\hline $\begin{array}{c}\text { Decreased water level on Rivers } \\
\text { and streams }\end{array}$ & $\begin{array}{c}15 \\
4\end{array}$ & $\begin{array}{c}\text { Think for } \\
\text { alternative } \\
\text { irrigation method }\end{array}$ & $\begin{array}{c}10 \\
0\end{array}$ & $\begin{array}{l}\text { Search for crops that } \\
\text { adapt on dry }\end{array}$ & $\begin{array}{l}5 \\
0\end{array}$ & $\begin{array}{l}\text { Rain water } \\
\text { harvesting }\end{array}$ & $\begin{array}{l}8 \\
7\end{array}$ \\
\hline $\begin{array}{l}\text { Increased infection rate of disease } \\
\text { on crops }\end{array}$ & $\begin{array}{c}14 \\
9\end{array}$ & Using medicine & $\begin{array}{c}14 \\
5\end{array}$ & $\begin{array}{l}\text { Using disease } \\
\text { resistance variety }\end{array}$ & $\begin{array}{l}5 \\
6\end{array}$ & & \\
\hline $\begin{array}{l}\text { Increased infection of disease on } \\
\text { livestock }\end{array}$ & $\begin{array}{c}16 \\
8\end{array}$ & Treatment & $\begin{array}{c}16 \\
8\end{array}$ & & & & \\
\hline $\begin{array}{l}\text { Increased infection rate of disease } \\
\text { on human }\end{array}$ & $\begin{array}{c}17 \\
1 \\
\end{array}$ & Treatment & $\begin{array}{c}17 \\
1\end{array}$ & & & & \\
\hline Decreased pasture/grassland & $\begin{array}{c}14 \\
1 \\
\end{array}$ & $\begin{array}{c}\text { Pasture } \\
\text { management }\end{array}$ & $\begin{array}{c}14 \\
1 \\
\end{array}$ & & & & \\
\hline $\begin{array}{c}\text { Increased mosquito and } \\
\text { house fly }\end{array}$ & $\begin{array}{c}17 \\
4 \\
\end{array}$ & Using mosquito nets & $\begin{array}{c}17 \\
4 \\
\end{array}$ & Use repellents & $\begin{array}{l}5 \\
5\end{array}$ & & \\
\hline Increased alien and invasive plants & $\begin{array}{c}17 \\
9\end{array}$ & $\begin{array}{l}\text { Remove and use to } \\
\text { make bio-briquettes }\end{array}$ & $\begin{array}{c}11 \\
5\end{array}$ & $\begin{array}{l}\text { Use as fodder for } \\
\text { animals }\end{array}$ & $\begin{array}{l}5 \\
5\end{array}$ & $\begin{array}{l}\text { Use as } \\
\text { compost } \\
\text { manure }\end{array}$ & $\begin{array}{l}8 \\
0\end{array}$ \\
\hline Increased crop damage rate by & 14 & Changing on the & 14 & Using insecticides & 1 & & \\
\hline
\end{tabular}




\section{Journal of Ecology \& Natural Resources}

\begin{tabular}{|c|c|c|c|c|c|c|}
\hline insects & 8 & crops & 3 & & 3 & \\
\hline Changing on plant phenology & $\begin{array}{c}11 \\
4\end{array}$ & $\begin{array}{c}\text { Changing on the } \\
\text { crops }\end{array}$ & $\begin{array}{c}10 \\
9\end{array}$ & & & \\
\hline
\end{tabular}

Table 4: Indicators and local people's adaptation strategies to cope with climate change $(n=204)$, Total Number is more than 204 because of multiple responses.

\section{Conclusion}

Results from the descriptive analysis of respondents interviewed, key informant interaction and focus group discussion revealed that the most of local people in the study area were perceived the effects of climate change. The respondents felt change in temperature, drying of land, drying of streams and rivers had increased while rainfall was also decreased over last 15 years. The respondents argued that low wind velocity was due to the increase of forest area. People also had the bitter experiences about the invasion of alien and exotic species in their farms and nearby forests $(87.7 \%)$ and decrease of area of pasture or grasslands (69.1\%), increased diseases on crops and livestock. Hence, the local people planned to use different adaptation strategies such as harvesting rain water, controlling alien and invasive plant species by making bio briquette, compost manures; farming the resistance varieties of crops to cope with increased rate of insects and disease. However, the lack of sufficient knowledge and sources, people's livelihood are under grave threat due to climate change impacts. Therefore, it's urgent to focus on capacity building of the famers to cope with changing climate and the policy makers, planners and donor agencies should develop area focussed research and development strategies.

\section{Acknowledgements}

We would like to thank District forest office of Kaski and Tanahun for granting permission to conduct this research work. We also extend our thanks to USAID funded Hariyo Ban Program, WWF Nepal for granting the $\mathrm{PhD}$ research grants. Our sincere thanks go to local people of Tanaun and Kaski who support and provide the information about issues of climate change and its effects.

\section{References}

1. Eriksson M, Xu J, Shrestha AB, Vaidya RA, Santosh N, Sandström K (2009) The changing Himalayas: impact of climate change on water resources and livelihoods in the greater Himalayas: International centre for integrated mountain development (ICIMOD).
2. Romieu E, Welle T, Schneiderbauer S, Pelling $M$, Vinchon C (2010) Vulnerability assessment within climate change and natural hazard contexts: revealing gaps and synergies through coastal applications. Sustainability Sci 5(2): 159-170.

3. Manandhar S, Vogt DS, Perret SR, Kazama F (2011) Adapting cropping systems to climate change in Nepal: a cross-regional study of farmers' perception and practices. Regional Environ Change 11(2): 335348.

4. Gentle P, Maraseni TN (2012) Climate change, poverty and livelihoods: adaptation practices by rural mountain communities in Nepal. Environ Sci Policy 21: 24-34.

5. Amjath Babu T, Krupnik TJ, Kaechele H, Aravindakshan S, Sietz D (2016) Transitioning to groundwater irrigated intensified agriculture in SubSaharan Africa: An indicator based assessment. Agricul Water Manag 168: 125-135.

6. Ayanlade A, Radeny M, Morton JF (2017) Comparing smallholder farmers' perception of climate change with meteorological data: A case study from southwestern Nigeria. Weather Climate Extremes 15: 24-33.

7. Adger WN (2003) Social capital, collective action, and adaptation to climate change. Economic Geograp 79(4): 387-404.

8. Chalise S, Naranpanawa A (2016) Climate change adaptation in agriculture: A computable general equilibrium analysis of land-use change in Nepal. Land Use Policy 59: 241-50.

9. Nagoda S, Nightingale AJ (2017) Participation and Power in Climate Change Adaptation Policies: Vulnerability in Food Security Programs in Nepal. World Develop 100: 85-93.

10. Joshi B, Ji W, Joshi NB (2017) Farm households' perception on climate change and adaptation 


\section{Journal of Ecology \& Natural Resources}

practices: A case from mountain district of Nepal. Int J Climate Change Strategies and Manag 9(4): 433-445.

11. Dinerstein E, Loucks C, Wikramanayake E, Ginsberg J, Sanderson E, et al. (2007) The fate of wild tigers. AIBS Bulletin 57(6): 508-514.

12. Nhemachena C, Hassan R (2007) Micro-level analysis of farmers adaption to climate change in Southern Africa: Intl Food Policy Res Inst.

13. Falaki A, Akangbe J, Ayinde O (2013) Analysis of climate change and rural farmers' perception in North Central Nigeria. J Human Eco 43(2): 133-140.

14. Mertz O, Mbow C, Reenberg A, Genesio L, Lambin EF, et al. (2011) Adaptation strategies and climate vulnerability in the Sudano-Sahelian region of West Africa. Atmosph Sci Let 12(1): 104-108.

15. Maddison D (2007) The perception of and adaptation to climate change in Africa: The World Bank.

16. Budhathoki NK (2017) Climate Change: Perceptions, Reality and Agricultural Practice: Evidence from Nepal.

17. Libois F, Somville V (2018) Fertility, household size and poverty in Nepal. World Devel 103: 311-322.

18. Atreya K, Pyakurel D, Thagunna KS, Bhatta LD, Uprety Y, et al. (2018) Factors Contributing to the Decline of Traditional Practices in Communities from the Gwallek-Kedar area, Kailash Sacred Landscape, Nepal. Environ Manage 61(5): 741-755.

19. Joshi GR, Joshi B (2017) Household food security: Trends and determinants in mountainous districts of Nepal. Future Food: J Food Agri Society 5(2): 42-55.

20. Uddin MN, Bokelmann W, Dunn ES (2017) Determinants of Farmers' Perception of climate change: A case study from the Coastal Region of Bangladesh. Ame J Climate Change 6(1): 151.

21. Vedwan N, Rhoades RE (2001) Climate change in the Western Himalayas of India: a study of local perception and response. Climate Res 19(2): 109-117.

22. Revi A (2008) Climate change risk: an adaptation and mitigation agenda for Indian cities. Environ Urban 20(1): 207-229.
23. Devkota RP (2014) Climate change: trends and people's perception in Nepal. J Environ Protect 5(4): 255-265.

24. Piya L, Maharjan KL, Joshi NP (2012) Perceptions and realities of climate change among the Chepang communities in rural mid-hills of Nepal. J Contempor India Studies: Space Society, Hiroshima University 2: 35-50.

25. Chaudhary P, Rai S, Wangdi S, Mao A, Rehman N, et al. (2011) Consistency of local perceptions of climate change in the Kangchenjunga Himalaya landscape. Current Science 101(4): 504-513.

26. Devkota RP, Pandey VP, Bhattarai U, Shrestha H, Adhikari S, et al. (2017) Climate change and adaptation strategies in Budhi Gandaki River Basin, Nepal: a perception-based analysis. Climatic Change 140(2): 195-208.

27. Uprety Y, Shrestha UB, Rokaya MB, Shrestha S, Chaudhary RP, et al. (2017) Perceptions of climate change by highland communities in the Nepal Himalaya. Climate Develop 9(7): 649-661.

28. Legesse B, Ayele Y, Bewket W (2013) Smallholder farmers' perceptions and adaptation to climate variability and climate change in Doba district, west Hararghe, Ethiopia. Asian J Empirical Res 3(3): 251265.

29. Tambo JA, Abdoulaye T (2013) Smallholder farmers' perceptions of and adaptations to climate change in the Nigerian savanna. Regional Environ Change 13(2): 375-388.

30. Roco L, Engler A, Bravo-Ureta B, Jara-Rojas R (2014) Farm level adaptation decisions to face climatic change and variability: Evidence from Central Chile. Environ Sci Policy 44: 86-96.

31. Banerjee RR (2015) Farmer's perception of climate change, impact and adaptation strategies: a case study of four villages in the semi-arid regions of India. Natural Hazards 75(3): 2829-2845.

32. Suberi B, Tiwari KR, Gurung D, Bajracharya RM, Sitaula BK (2018) People's perception of climate change impacts and their adaptation practices in Khotokha valley, Wangdue, Bhutan. 


\section{Journal of Ecology \& Natural Resources}

33. Deressa TT, Hassan RM, Ringler C (2011) Perception of and adaptation to climate change by farmers in the Nile basin of Ethiopia. J Agricul Sci 149(1): 23-31.

34. Abidoye BO, Kurukulasuriya P, Mendelsohn R (2017) South-East Asian farmer perceptions of climate change. Climate Change Economics 8(3): 174-176.

35. Sanogo K, Binam J, Bayala J, Villamor GB, Kalinganire A, et al. (2017) Farmer's perceptions of climate change impacts on ecosystem services delivery of parklands in southern Mali. Agroforestry systems 91(2): 345-361.
36. Woods BA, Nielsen HØ, Pedersen AB, Kristofersson D (2017) Farmers' perceptions of climate change and their likely responses in Danish agriculture. Land Use Policy 65: 109-120.

37. Okonya JS, Syndikus K, Kroschel J (2013) Farmers' perception of and coping strategies to climate change: Evidence from six agro-ecological zones of Uganda. J Agricul Sci 5(8): 252.

38. Gukurume S (2013) Climate change, variability and sustainable agriculture in Zimbabwe's rural communities. Russian J Agricul Socio-Economic Sci 14(2): 89-100. 